\title{
Liberalized Trade and Worker-Firm Matching
}

By Carl Davidson, Fredrik Heyman, Steven Matusz, Fredrik Sjöholm and Susan Zhu ${ }^{1}$

To allocate workers efficiently, the labor market faces an enormously complex task. Not only must it generate a wage profile consistent with full employment, but it must also correctly match workers that differ in ability, education and physical attributes with firms, both across and within sectors, that differ in the sophistication of the technology that they use in production. Moreover, the process is dynamic, as globalization and domestic shocks give rise to almost constant reallocation. It is therefore not surprising that the labor market functions imperfectly, with significant resources either idle or underutilized at any point in time. Unfortunately, particularly when labor market breakdowns become severe, many look for a scapegoat and, at least in the popular press, globalization is often a target. Concerns are expressed that moving production to low-wage countries contributes to our unemployment problem and that the outsourcing of some tasks forces domestic workers to accept jobs that they are overqualified for. Yet, the role that globalization plays in enhancing or hampering the performance of the labor market is not well understood. In this paper, we offer some empirical results on one aspect of this issue -- the effect of globalization on the ability of the labor market to match heterogeneous workers to jobs offered by heterogeneous firms. ${ }^{2}$

The idea that workers and firms might be mismatched is not new. Becker (1973) and Roy (1951) were both concerned with the ability of the market to match agents in markets with twosided heterogeneity. Becker (1973) focused on marriage markets and argued that, under reasonable assumptions concerning household production, it would be optimal to pair men and

\footnotetext{
${ }^{1}$ Matusz, Department of Economics, Michigan State University, East Lansing, MI 48824 (matusz@msu.edu).

2 The results presented here complement the much more extensive analysis in Davidson, et al (2011).
} 
women with similar attributes. In the context of the labor market, such positive assortative matching is equivalent to pairing highly skilled workers with firms using the most sophisticated technology within the industry. A sizeable search theoretic literature has developed exploring conditions under which positive assortative matching is optimal and conditions under which the labor market generates this pattern of matching. Attempts to measure the extent of positive assortative matching can be found in Pencavel (1998) and Abowd, Kramarz and Margolis (1999); and attempts to measure the losses from imperfect matching within an industry can be found in Hsieh and Klenow (2009). None of these studies deals with the issue of globalization.

Our paper contributes to the small but growing literature on international trade with heterogeneous labor (see Davidson and Sly 2011 for a survey). In almost all such work, firms within an industry are assumed to be identical, so the focus is on sorting workers across sectors, and labor markets are competitive, so that sorting is efficient. ${ }^{3}$ In contrast, Davidson, Matusz and Shevchenko (2008), henceforth DMS, develop a model with two-sided labor-market heterogeneity within an industry in which informational problems about job opportunities leads to imperfect matching. Their main finding is that lower trade costs that increase export activity by domestic firms tends to improve matching while increased import penetration may lead to less efficient matching. In the next section we summarize the economic forces that drive these results. In Section 3 we describe the data from Sweden that we use to test these predictions and then make use of the methodologies of Pencavel (1998) and Abowd, Kramarz and Margolis (1999) to offer some preliminary empirical results that support the predictions.

\footnotetext{
${ }^{3}$ Yeaple (2005) and Sampson (2011) are exceptions in that they have two-sided heterogeneity within the labormarket of a single industry. But, both assume competitive labor markets so that sorting across firms is perfect.
} 


\section{Intuition}

DMS develop a model with two types of labor, high-skill and low-skill, in which ex ante identical firms must select a technology to use when entering the market. Adopting a basic technology allows a firm to employ workers of both skill levels while offering low wages; whereas firms that adopt an advanced technology can only employ highly-skilled workers and must pay high wages. In equilibrium, firms of both types co-exist. The novel feature of the DMS model is that workers must search for jobs across firms differentiated by their chosen technologies. Since search is costly, workers and firms may be mismatched - a worker accepts a less than ideal job if the expected benefit from continuing to search is lower than the cost of additional search. DMS assume that highly-skilled workers are better suited for the jobs offered by firms using the advanced technology, so that positive assortative matching is optimal. Thus, imperfect matching occurs when the two types of firms earn revenues that are similar, so that firms using the basic technology can afford to offer highly-skilled workers a wage that is high enough to entice them to stop searching.

Output markets are perfectly competitive and firms can earn revenue from two sources: domestic sales and, if they can cover the cost of accessing world markets, exports. As in any model with heterogeneous firms, it is the firms that use the modern technology that hire the better workers, produce more output, use more capital and have an easier time covering the cost of exporting than their counterparts. Thus, as trade costs fall, these firms benefit disproportionally and this widens the gap between the revenues earned by the two types of firms. Consequently, a fall in trade costs that makes it easier for domestic firms to export makes it harder for the weakest firms to recruit the best workers. To be precise, firms that use the basic technology will now have to increase their offer to high-skill workers, making adoption of that 
technology less profitable. As a result, globalization leads to more highly-skilled workers being employed by firms using the advanced technology - matching becomes more efficient.

When falling trade costs lead to greater import penetration, the impact on matching is more nuanced. ${ }^{4}$ An increase in imports pushes down the domestic price, lowering the revenue earned by all firms from domestic sales. On the one hand, firms that use the modern technology produce more output than their competitors and they therefore suffer disproportionally from the drop in price. However, these firms are also more selective in their hiring practices and thus spend more time trying to fill their vacancies than their competitors. These two effects work in opposite directions. If the output gap between the two types of firms is large or if the time that it takes firms to fill vacancies is relatively small, increased import penetration will narrow that gap between the revenues earned by the two types of firms and this will make it easier for weak firms to attract good workers. In such a case, globalization results in less efficient matching. This result can be reversed if the output gap is small and the time that it takes strong firms to fill vacancies is relatively long. It follows that the impact of increased import activity on the efficiency of matching is ambiguous. ${ }^{5}$

\section{Empirical Results}

\section{A. Data Sources}

We use matched worker-firm data provided by Statistics Sweden, enabling us to examine the sorting of workers across firms and over time. The analysis covers 1995-2005 and uses all private-sector firms with at least 20 employees. We have data on a large number of firm

\footnotetext{
${ }^{4}$ This discussion draws on insights from Davidson and Matusz (2011) which extends DMS to a monopolisticallycompetitive setting.

${ }^{5}$ In addition, lower prices for imported intermediates benefits all firms, with larger firms benefiting more than smaller firms. This effect is absent from the DMS analysis since there are no intermediate goods in their model.
} 
variables including capital stocks, sales, value added, firm size, ownership and industry affiliation and so on. The worker data set contains approximately 2 million individuals per year (accounting for roughly $50 \%$ of the labor force), and includes information on workers' wages, education, labor market experience, gender and occupation. Wages are full-time equivalent and include all types of compensation, including bonuses and non-pecuniary compensation. There is a relatively high degree of mobility of workers across firms, with 34 percent of the workers observed in at least two different firms and with a median of 30 movers per firm. Our linked data set consists of over 9 million person-year observations and about 8,500 firms.

\section{B. Worker and Firm Types}

We want to account for both observable and unobservable attributes when measuring the quality of workers and firms. To estimate firm and worker non-observable attributes we regress worker compensation on firm and worker characteristics controlling for firm and worker fixed effects. $^{6} \quad$ Observed attributes include experience squared, higher-degree polynomials of experience, a blue collar worker indicator, capital intensity, firm size (number of employees), labor productivity (value added per worker), share of labor force with tertiary education, manufacturing indicator, share of female workers and its interaction with the manufacturing indicator. The result for the wage regression is listed in Table 1 of Davidson et al. (2011). We use firm and worker total effects (both observed and unobserved effects) to capture the total quality of firms and workers. Using the median value of firm and worker total effects as the cutoff, we divide firms into high-tech and low-tech and workers into high-skilled and low-skilled.

\footnotetext{
${ }^{6}$ Our approach modifies Abowd, et al (1999) by adding firm characteristics.
} 


\section{A Non-Parametric Look at the Worker-Firm Matching}

The matching between firms and workers can be classified into two types. A positive assortative match involves a high-skilled worker employed at high-tech firm or a low-skilled worker employed at low-tech firm, By contrast, a mismatch involves a high-skilled worker employed at a low-tech firm or low-skilled worker employed at a high-tech firms. Let $\pi_{\mathrm{ij}}$ represent the percent of employed workers defined by skill $i=H, L$ employed at a firm defined by technology $j=H, L .^{7}$ As shown in Table 1 , the value of $\pi_{\mathrm{HH}}$ increased by nearly 3 percentage points between 1995 and 2005, while $\pi_{\mathrm{LL}}$ increased by 2 percentage points. Evidently, positive assortative matching increased over the sample period. During this time period, the median tariff imposed on Swedish exports fell from $1.44 \%$ to $0.17 \%$.

Table 1. Distribution of workers and firms by skills and technology 1995 and 2005.

1995

\begin{tabular}{|c|c|c|c|c|}
\hline & High-tech firms & Low-tech firms & High-tech firms & Low-tech firms \\
\hline rorkers & $25.76 \%$ & $24.24 \%$ & $28.65 \%$ & $21.35 \%$ \\
\hline low-skill workers & $24.33 \%$ & $25.67 \%$ & $22.32 \%$ & $27.68 \%$ \\
\hline
\end{tabular}

Note: The calculations use the matched employer-employee data provided by Statistics Sweden. The classification of worker and firm types is described in Section II.B.

One way of quantifying the change in the matching pattern is to calculate $\left(\pi_{\mathrm{HH}}+\pi_{\mathrm{LL}}\right)$ $-\left(\pi_{\mathrm{HL}}+\pi_{\mathrm{LH}}\right)$. This statistic, showing the difference between the share of positive assortative matches and the share of mismatches, was $2.86 \%$ in 1995 , growing to $12.66 \%$ in $2005{ }^{8}$

We can alternatively examine worker transitions between firms, addressing the question of the type of re-employment a type-i worker is likely to obtain after separation from a type- $j$ firm. Keeping in mind that the theory suggests that the effects of reduced trade costs ought to

\footnotetext{
${ }^{7}$ By definition, $\pi_{\mathrm{iH}}+\pi_{\mathrm{iL}}=0.5$ since skill group is identified by the median worker.

${ }^{8}$ Pencavel (1998) measures the degree of sorting as a ratio of the fraction of positive assortative match to the fraction of mismatch. It is easy to see that there is a monotonic increasing relationship between our measure and the Pencavel measure. However, unlike the Pencavel measure, our measure is bounded between -1 and 1 .
} 
differ according to whether an industry is export-oriented or import-competing, we refine the data by defining an industry as export-oriented if it had positive net exports in 1995, and importcompeting otherwise. Looking at job-to-job transitions organized in this way, our data show that between 1995 and 2005 high-skilled workers experienced improved matching, especially in export-oriented industries. Firm-worker matching also improved for low-skilled workers. However, unlike high-skilled workers, they saw a larger improvement in matching at importcompeting industries. For instance, $61 \%$ of the high-skill workers who separated from high-tech firms become re-employed at other high-tech firms in export-oriented industries. That number falls to $54 \%$ in import-competing industries. Continuing to focus on high-skilled workers, $40 \%$ who separated from low-tech firms became re-employed in high-tech firms in export-oriented industries, with only $28 \%$ becoming re-employed in high-tech firms in import-competing industries. For low-skilled workers, 56\% who separated from high-tech firms found reemployment by low-tech firms in import-competing industries, with $35 \%$ finding re-employment at low-tech firms when we look at export-oriented industries. In additon, $76 \%$ of low-skilled workers who separated from low-tech firms were re-employed by low-tech firms in exportoriented industries, while the number increased to $90 \%$ for import-competing industries.

\section{Empirical Estimation}

We focus on the impact of trade openness on the degree of matching between workers and firms. Because the intuition outlined above suggests that the impact may differ between export-oriented and import-competing industries, we use the following specification:

$$
\text { Matching }_{g t}=\alpha_{0}+\alpha_{1} \text { Open }_{g t}+\alpha_{2} \text { Export oriented }_{g} \cdot \text { Open }_{g t}+D_{t}+D_{g}+\mu_{g t}
$$


where $g$ indexes industries; $t$ indexes years; Matching $g t$ represents the degree of matching between workers and firms for industry $g$ and year $t$ Open $_{g t}$ measures the degree of openness;

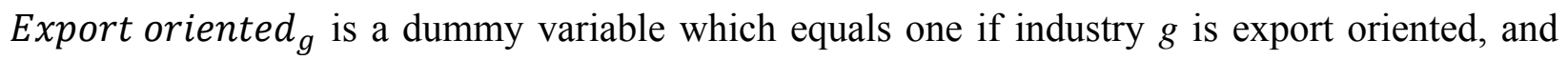
zero if the industry is import competing; $D_{t}$ and $D_{g}$ represent year and industry fixed effects, controlling for omitted macroeconomic factors and cross-industry differences in production technology that might influence the degree of matching; and $\mu_{g t}$ is the error term that includes all unobserved factors that may affect the degree of matching. The degree of matching is measured by $\left(\pi_{\mathrm{HH}}+\pi_{\mathrm{LL}}\right)-\left(\pi_{\mathrm{HL}}+\pi_{\mathrm{LH}}\right)$ for each industry at a three-digit level of the Swedish Industrial Classification (SNI) in each year over the sample.

We use foreign tariffs as our measure on openness. We aggregate the tariff data from the UNCTAD TRAINS database at a six-digit HS level up to a three-digit SNI level using export shares in 1995 as the weights. A reduction in foreign tariffs imposed on Swedish exports increases market access for Swedish firms. One advantage with this measure is that it can be considered as exogenous to labor market sorting in Swedish industries.

The estimation results are reported in Table 2. Our estimates of $\alpha_{1}$ are statistically insignificant, suggesting that the reduction of foreign tariffs had no significant effects on the degree of matching for import-competing industries.

In contrast, $\boldsymbol{\alpha}_{2}$ captures the differential effect of foreign tariffs on export-oriented industries relative to that on import-competing industries. In column 1 our point estimate for $\boldsymbol{\alpha}_{2}$ is -0.344 with a standard error of 0.0128 , indicating that reduced foreign tariffs improved the degree of matching for export-oriented industries relative to that for import-competing industries. 
As shown at the bottom of column 1 , the F-statistic of the test of $\boldsymbol{\alpha}_{\mathbf{1}}+\boldsymbol{\alpha}_{\mathbf{2}}<0$ is 7.11 with a $p$-value of 0.009 , suggesting that reduced foreign tariffs significantly improved the degree of matching for export-oriented industries.

In column 2 we replace contemporaneous tariffs with a one-year lag to account for the possible lagged impact of tariff reductions on matching. Our point estimate for the coefficient on lagged tariffs is -0.0462 with a standard error of 0.0124 , suggesting a slightly bigger effect on the labor market sorting than contemporaneous tariffs used in column 1.

Table 2. Openness and matching in Swedish industry 1995-2005.

\begin{tabular}{|c|c|c|}
\hline & (1) & (2) \\
\hline Foreign tariffs $\left(\boldsymbol{\alpha}_{1}\right)$ & $\begin{array}{l}0.00041 \\
(0.00037)\end{array}$ & $\begin{array}{l}0.00068 \\
(0.00052)\end{array}$ \\
\hline Export orientated $\times$ Foreign tariffs $\left(\boldsymbol{\alpha}_{2}\right)$ & $\begin{array}{l}-0.0344 * * * \\
(0.0128)\end{array}$ & $\begin{array}{l}-0.0462 * * * \\
(0.0124)\end{array}$ \\
\hline F-test: $\alpha_{1}+\alpha_{2}<0$ & $7.11 * * *$ & $13.68 * * *$ \\
\hline $\mathrm{R}^{2}$ & 0.088 & 0.075 \\
\hline $\mathrm{a}$ & 933 & 824 \\
\hline Industries & 94 & 90 \\
\hline
\end{tabular}

\section{Conclusion}

There are theoretical arguments to be made that the process of globalization can shape the environment under which workers are matched with firms. Here we report some of the results that we have found in the context of a larger project where we have been analyzing the effect of globalization on worker-firm sorting. Our analysis suggests an empirical link between globalization and worker-firm sorting, and the correlation between the two runs in the expected 
direction. We more thoroughly explore the data, slicing it in numerous different ways and subjecting the analysis to many robustness checks in Davidson, et al (2011).

The Swedish data is nearly ideal for exploring the impact of globalization on worker-firm matching. As is evident in this session, access to matched worker-firm data is expanding and it is being increasingly used to investigate issues relevant to the nexus of international trade and labor markets. We hope that the results that we report here and in Davidson et al (2011) are sufficiently intriguing to encourage others to join the exploration. 


\section{REFERENCES}

Abowd, John M., Francis Kramarz and David N. Margolis. 1999. "High wage workers and high wage firms" Econometrica 67(2): 251-333.

Becker, Gary. 1973. "A Theory of Marriage: Part I" Journal of Political Economy 81(4): 813-46.

Davidson, Carl, Fredrik Heyman, Steven Matusz, Fredrik Sjöholm and Suszan Zhu.

2011. "Globalization and Imperfect Labor Market Sorting" Working paper Michigan State University and Research Institute of Industrial Economics.

Davidson, Carl and Steven Matusz. 2011. "A Model of Globalization and FirmWorker Matching: How Good is Good Enough?" forthcoming in International Review of Economics and Finance

Davidson, Carl, Steven Matusz and Andrei Shevchenko. 2008. "Globalization and Firm Level Adjustment With Imperfect Labor Markets.” Journal of International Economics 75(2): 295-309.

Davidson, Carl and Nicholas Sly. 2011. "Trade and the Labor Market: Recent Developments and New Frontiers" forthcoming in Oxford Handbook on International Commercial Policy, M. Kreinin and M. Plummer, eds., Oxford University Press.

Hsieh, Chang-Tai and Peter Klenow. 2009. "Misallocation and Manufacturing TFP in China and India” Quarterly Journal of Economics 124(4): 1403-48.

Pencavel, John. 1998. “Assortative Mating by Schooling and the Work Behavior of Wives and Husbands" American Economic Review 88(2): 326-29. 
Roy, Andrew. 1951. "Some Thoughts on the Distribution of Earnings" Oxford Economic Papers 3: 135-46.

Sampson, Thomas. 2011. "Selection Into Trade and Wage Inequality” London School of Economics Working Paper.

Yeaple, Stephen. 2005. “A Simple Model of Firm Heterogeneity, International Trade, and Wages" Journal of International Economics 65: 1-20. 